\title{
ESSAYS
}

\section{SCIENTIFIC INNOVATION AND ENVIRONMENTAL PROTECTION: SOME ETHICAL CONSIDERATIONS}

\author{
BY \\ CAROL M. ROSE*
}

This Essay explores a fundamental problem that scientific research poses for environmental ethics. Scientific research has brought great gains to our knowledge of the environment, but the motivations for scientific research tend systematically to run counter to environmental protection. While research scientists may have many different individual motivations for their work, economic actors are most likely to pay attention to and fund scientific research agendas that can lead to economically valuable information, which means that the research results must be capable of belonging to some entity. However, environmental harms and benefits are generally not experienced as belonging to anyone, because their diffuseness makes them difficult to reduce to property. The result is a pattern in which scientific research veers first towards products that can be "propertized," and only later, if at all, towards the environmental consequences of such new products.

Environmental ethics need to address this research gap. This Essay explores some ways in which publicly funded research and regulatory programs might do so. It concludes that, in spite of ethical doubts that have been raised about market-based environmental regulation, such programs deserve closer attention; they may have ethical value that can offset ethical qualms, because they can motivate

* (c) Carol M. Rose, 2002. Gordon Bradford Tweedy Professor of Law and Organization, Yale University. For helpful comments on earlier versions of this essay, I would like to thank the participants at the Yale Program in Bioethics, as well as members of the Lewis \& Clark Law School community. For able research assistance, I would like to thank Chris Stevens of the Yale Law School. 
economic actors to channel research toward the environment, and thus help to narrow the research gap as between "propertized" goods and environmental goods.

Scientific research efforts and the technological innovations that follow from them are among the hallmarks of our age. Indeed, in large measure, progress in scientific knowledge and technology is exactly what people mean by the term "progress" more generally. Like every other aspect of life in the twenty-first century, the natural environment is greatly affected by science. This fact necessarily has ethical implications, and those implications are in turn the subject of this essay.

I do not open with an empty slate, of course, because others have written on this important subject of the relationship between science and environmental ethics. I can begin with two viewpoints that I do not share, but that are important all the same in the literature of environmental ethics, because they frame the debate by setting markers on opposite ends of the spectrum.

One of these viewpoints is perhaps best expressed by Peter Huber, himself both a lawyer and an engineer, and now a frequent writer on environmental legal subjects. ${ }^{1}$ Huber presents scientific and technological innovation as overwhelmingly beneficial to the environment. Newer technologies, he argues, are generally-if not universally-safer than the old ones they replace. ${ }^{2}$ One major reason, he says, is that newer technologies tend to concentrate rather than disperse risks, and concentrated risks can be managed more efficiently, cheaply, and less dangerously than risks that are decentralized. ${ }^{3}$ On this argument, large industrial plants should be much safer for employees than widely dispersed smaller mills because the larger units' practices can be observed, regulated, and regularized more easily. Pollution control should be similar: Large centralized utilities are more amenable to pollution reduction than, say, individual household coal or wood fires, again because the large plants' emissions can be observed, detoxified, and monitored in a way that takes advantage of scale economies. ${ }^{4}$

A very different viewpoint argues that modern scientific innovation is inherently anti-environmental. A chief proponent of this view is Carolyn Merchant, who writes on the history of scientific thought. One of her

\footnotetext{
1 For this and other information on Mr. Huber, see his Web site at http://www.phuber.com. (last visited Nov. 23, 2002). His most recent book on the environment is Hard Green: Saving the Environment from the Environmentalists: A Conservative Manifesto (1999).

2 Peter Huber, Safety and the Second Best: The Hazards of Public Risk Management in the Courts, 85 ColuM. L. REV. 277-79, 295-99 (1985) [hereinafter Second Best]. For a similar argument, see Peter Huber, The New-Old Division in Risk Regulation, 69 VA. L. REv. 1025, 107375 (1983) [hereinafter New-Old Division] (comparing relative safety of new risks to old ones, arguing that newer risks are generally safer).

${ }^{3}$ Second Best, supra note 2, at 299-305.

4 Id. at 302-03 (using as example, among others, a comparison of wood stoves to modern nuclear power utilities).
} 
primary works is The Death of Nature, ${ }^{5}$ which traces the impact on the environment of the seventeenth-century revolution in scientific thought. She argues that since the seventeenth century, the central attitude of scientific endeavor has been one of conquest-nature has to be dominated rather than treated with respect and sympathy. ${ }^{6}$ Merchant's argument is a kind of testosterone theory of modern science, complete with a gendered set of attitudes, with nature playing the role of the conquered female. ${ }^{7}$ Quite aside from the gender issue, however, Merchant holds modern science accountable for some very serious damage to the environment, and more fundamentally, to our ways of even thinking about the environment. In her view, the modern understanding of science has privileged technological fixes over more modest efforts to live in harmony with nature. It has elevated the sense of sight-cool, distant, and instantaneously synopticover the more engaged and time-sensitive senses of hearing and touching, where understanding emerges over time through intimate connection; by the same token, modern science has encouraged deterministic reasoning to triumph over more narrative, contingent, and humanistic understandings of the world. ${ }^{8}$ In sum, this machismo-laden understanding of science results in an attitude that applauds a heedless and triumphalist trashing of the earth and its natural structures. ${ }^{9}$

For a variety of reasons, I am a little skeptical of both viewpoints. First, it seems to me that people in science have enormously varied attitudes about the subjects on which they work. Moreover, both Merchant's and Huber's viewpoints have some convincing elements, and thus each casts some doubt on the other. Undoubtedly, as Huber argues, science has delivered to us vastly better means for monitoring and controlling environmental harms. But it is also true, as Merchant argues, that scientific knowledge has enabled some of the very same harms to come into being in the first place. Hence it is important to take seriously the ethical implications of scientific investigation for environmental well being, particularly the idea that scientific research may run in directions that are at best tangential - and at worst opposite - to those of environmental well being.

Legal theorists have identified one approach that may be particularly relevant to this inquiry into the potentially divergent directions between science and the environment. That approach has information as its subject

5 Carolyn Merchant, The Death of Nature: Women, Ecology and the Scientific REVOLUTION (1980) [hereinafter DEATH OF NATURE].

6 Id. at $2-3$.

7 Id. at 169-72 (describing Francis Bacon's prescription for the new scientific research).

8 Carolyn Merchant, The Theoretical Structure of Ecological Revolutions, 11 ENVTL. REV. 265, 273 (1987); see also Carol M. Rose, Seeing Property, in Property and PERSUASION: Essays ON THE HISTORY, THEORY, AND RHETORIC OF OWNERSHIP 267, 270-71 (1994) (discussing one critique of modern science and its relationship to sense of sight). For a classic discussion of the objectifying qualities of vision, see Hans Jonas, The Nobility of Sight: A Study in the Phenomenology of the Senses, 14 PHIL. \& Phenomenological Res. 507, 507-11, 514-19 (1954).

9 See DEATH OF NATURE, supra note 5, at 249-52 (describing modern reductionism as an outgrowth of attitudes of the seventeenth-century scientific revolution). 
matter, and considers information as an economic good. The idea is that in a certain sense information is a scarce good, and, as is the case with other scarce goods, the production of information responds to patterns of supply and demand. ${ }^{10}$

On this approach, one can think of scientific research as a producer of a kind of information. To be sure, the type of scientific research under discussion here may not be the deepest and most basic science-the science that goes so deep as to overlap with cosmology or metaphysics. According to. all reports, science at this most basic level has no utilitarian aims. Its pursuit is motivated by sheer love of learning-philosophia as the ancient Greeks said-or perhaps also by the quest for fame among others in the same areas of pure inquiry. But that is not the kind of scientific research at stake in this discussion. Of much greater interest is the class of scientific research efforts, and the technological pursuits that follow, that do have some expected uses, even though those uses may be remote.

Even with this kind of technological research, it is easy to believe that researchers are largely motivated by sheer curiosity and sheer love of learning-or simply by the fun of the research. ${ }^{11}$ But where practical gains can be made from scientific or technological knowledge, investment is likely to lubricate the research enterprise. And investment is the link between scientific research and the economics of information.

For example, the general press reported in early 1999 that a team of Harvard scientists had figured out how to slow the speed of light to the quite amazing rate of about thirty-eight miles per hour. ${ }^{12}$ Two years later they reportedly stopped light altogether, at least for a very brief moment. ${ }^{13}$ It is hard to believe that these researchers did their work just for the money rather than for the enormous excitement of learning. But whatever the scientists' motivations, some investors are likely to notice that there are practical applications of this slowing down or stopping of light-for example, making supercomputers that operate vastly more rapidly and with much-enhanced security. ${ }^{14}$ This means that further research into the slowing of light is highly likely to attract funding. Grants, graduate student theses, papers, conferences, and more intense research efforts are likely to follow.

Here too, I should say that I see nothing the matter with this pattern as a matter of principle. People make money from information all the time. For example, people who research business management and strategies use the

10 See, e.g., Anthony T. Kronman, Mistake, Disclosure, Information, and the Law of Contracts, 7 J. LEGAL STUD. 1, 13 (1978) (describing "deliberately acquired information" as information that is difficult to get and unlikely to be generated unless rewarded); RICHARD A. POSNER, ECONOMIC ANALYSIS OF LAW 36 (3d ed. 1986) (analogizing information to other kinds of property).

11 See, e.g., Paul Trachtman \& Peter Menzel, Redefining Robots, Smithsonian MaG., Feb. 2000 , at 96 (reporting on technological work on small robots that behave like insects).

12 Malcolm W. Browne, Researchers Slow Speed of Light to the Pace of a Sunday Driver, N.Y. TIMES, Feb. 18, 1999, at Al.

13 Douglas Bailey, Harvard Scientists Say They've Stopped Light, BosTON GLOBE, Jan. 18, 2001, at A3.

14 Id. 
information to make money in the stock market, and their purchases and sales send signals to the rest of us about firm value. Indeed, our contract law encourages people to make efforts to acquire information not just casually, but deliberately. ${ }^{15}$ On balance, it is undoubtedly a good thing that there are economic rewards for seeking information, because economic incentives can powerfully generate useful information, as well as powerfully slash misinformation. Hence I think it inappropriate to complain about the intrusion of mammon into scientific research-economic incentives are not undesirable as such, and they are probably inevitable under any circumstances.

A matter of considerably greater concern, however, is the proportion among the types of scientific information that result from economic incentives. More specifically, the problem is one of lopsidedness of information, in a shape that does not favor the environment. Consider the subjects that generate investment: All other things being equal, economic considerations are likely to move a greater quantity of funds, and at a more rapid pace, toward scientific and technological knowledge that can be applied toward private property and hence create more wealth for particular individuals or entities. A lesser quantity will move-and move more slowlytoward the environmental damages that these projects may cause. For example, given the ever-increasing market for automobiles, it is scarcely an accident that vast amounts of technological research went into the development and refinement of the internal combustion engine. But many years passed before anyone paid attention to the relationship between those engines and smog, with all its ill-effects on human health and environmental amenity. ${ }^{16}$

Why this disproportion? What is the reason for this information gap or lag with respect to environmental consequences? One major reason is the unpropertied character of environmental resources, and hence their inability to generate individual wealth. It is widely agreed that environmental resources are almost by definition those that do not belong to anyone in particular-a point routinely noted in the legal scholarship on environmental matters. ${ }^{17}$ Consider the air mantle, flowing waters, groundwater, the oceans, the ozone layer, wildlife and fish stocks, and similarly diffuse resources. Who owns them? Can they be owned at all, or should they be? On the latter point of "should," it is almost a point of pride among some environmental ethicists that no one really owns such things. Nature and nature's creatures,

15 Kronman, supra note 10 , at 13-14.

16 James E. Krier \& Edmund Ursin, Pollution and Policy: A Case Essay on California and Federal Experience WTTH Motor VeHICle AIR POLLUTION, 1940-1975, 77-86 (1977).

17 To illustrate this lack of property, environmental law textbooks often include a selection from Garrett Hardin's famous article, "The Tragedy of the Commons," in their introductory sections. See, e.g., Roger W. Findley \& Daniel A. Farber, Cases and Materials on ENVIRONMENTAL LAW 42 (5th ed. 1999) (citing Garrett Hardin, The Tragedy of the Commons, 162 Sci. 1243 (1968)); Robert V. Percival ET Al., Environmental Regulation: Law, SCIENCE, AND POLCY 58 (3d ed. 2000) (also citing Garrett Hardin, supra). For more on the "tragedy of the commons," see text at notes $19-20$, infra 
it is said, are things in themselves-things that should be independent of the subordination to human ends entailed in property. ${ }^{18}$

Having said this, it is indeed possible as a practical matter to claim some portion of environmental resources as property, and this partial claiming creates problems for resources in the aggregate. You can pump water from an underlying aquifer; you can remove a fish from the stocks of the sea; you can hunt a single caribou from the vast wild herd. But when you take these actions, your actions have an effect on the overall stocks of water or fish or caribou. What is difficult to own is not the individual bucket of water or the individual animal, but the larger stocks from which they derive, and which are affected by the taking of the individual. These larger stocks are the environmental resources-big, diffuse, slippery, often hidden, and generally quite intractable to claims of overall ownership.

There is a name that is widely used for resources of this kind: They are "commons" or "commons-es." More accurately, they are deemed "open access resources," because they have no managers or owners and because each such resource is open to all comers. ${ }^{19}$ Precisely because no one owns or manages these resources as wholes, they suffer the fate that supposedly comes to every commons-overexploitation and underinvestment, and ultimately depletion and decimation.

Fisheries are among the most widely studied common resources, and fisheries all too often illustrate what has come to be known as the "tragedy of the commons." ${ }^{20}$ A well-known pattern in open access fishing grounds is that too many fishers hunt too long and too diligently, with the result that the fishing ground is eventually fished out. Why does this happen? Suppose you are a fisher: If you restrain yourself and hold back on your catch, some other fisher simply will take your place, so that your conservation efforts only make others temporarily better off without preserving the fishing ground. Similarly, on the investment side, if you try to restock a declining fishery, the proceeds will go in large part to others, including those who have made no such investment, so that your payoff from investing in the common resource is some small fraction of your inputs. Who wants to be a patsy in this way? Surely not you, nor many others. Thus, even if everyone knows that the fishing grounds are over-fished, you may as well just go ahead and fish. ${ }^{21}$

Notice how different this situation is from that which generally occurs where someone or some group owns the resource, say in a private fishing

18 See Roderick Frazier NaSh, The Rights of Nature: A History of Environmental ETHICs 192 (1989) (describing radical environmentalists' efforts to "free" nature); see also id. at 199-213 (explicitly analogizing this environmental ethic to nineteenth-century abolitionism).

19 For the distinction between a "commons" (or "common pool resource"), which may be limited to a specific group of users, and "open access" resources, which are open to all, see

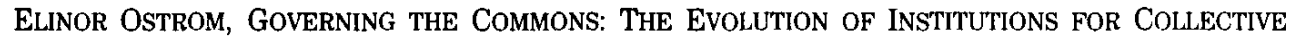
ACTION 23, 222 n.23 (1990) (drawing distinction).

20 The classic article is The Tragedy of the Commons, 162 SCI. 1243 (1968). However, the underlying theory was developed earlier for fisheries. H. Scott Gordon, The Economic Theory of a Common-Property Resource: The Fishery, 62 J. PoL. Econ. 124 (1954).

21 Gordon, supra note 20, at 132 (describing fishers' hopes for a "lucky catch"). 
area. Ownership concentrates costs and payoffs on the owner/actor. One does not generally expect private fishing ponds to be over-fished, because the owner pays attention and rations herself and others. But in the openaccess common fishing ground, the absence of property discourages careful management. Why bother, when others will collect all the payoffs and squander any gains from your careful behavior?

All these "commons" issues open a window on the relationship between scientific research and the environment. There is an information component to the commons story too. Just as no one in particular is rewarded for preserving open-access common resources, no one is rewarded for learning about them either, except insofar as learning is its own reward. Indeed, to some degree, the learning that pays off most immediately is learning how to exploit the "free" commons faster and more thoroughly than anyone else, so as to claim goods from the commons as one's own property before the commons give out. ${ }^{22}$

Property versus commons-this divergence between things that people own and things that they cannot own (or cannot own easily)-forms the core scenario for the information gap in general and the research gap in particular. We might well expect investment to flow toward research on the development of more efficient fishing gear or on the use of sonar for locating schools of edible fish, because once they are located and caught, the individual fish turn into the property of the fishers. This information pays off. But until very recently-and probably not even now-there was no proportionate investment in research about the interactions of species within whole marine ecosystems, ${ }^{23}$ or about the impacts of human fishing activities or pollutants on marine species that people do not care to eat. ${ }^{24}$ Like environmental information generally, much of this learning does not pay off, at least in any identifiable and immediate way to anyone in particular, even though it could pay off in major ways over long periods and to many people. Hence, marine environments remained largely mysterious until a belated catch-up game of learning, which itself followed on the heels of the threatened collapse of fisheries worldwide. ${ }^{25}$ This is the case even though fisheries are among the most studied of all environmental

22 See, e.g., Cory Hayden, Prospecting Taxonomies: Nations, Publics, Communities, in Changing Property Relations at THE TURn of THE Millennium (forthcoming 2003) (describing efforts to find plants in the public domain that may lead to pharmaceuticals) (on file with author).

23 See, e.g., Jeff Brax, Zoning the Oceans: Using the National Marine Sanctuaries Act and the Antiquities Act to Establish Marine Protection Areas and Marine Reserves in America, 29 ECOLOGY L.Q. 71, 73-75 (2002) (describing lack of scientific knowledge and governmental interest in marine environments until very recently); Harry N. Scheiber, Ocean Governance and the Marine Fisheries Crisis: Two Decades of Innovation-and Frustration, 20 VA. ENvTL. L.J. 119, 119-20 (2001) [hereinafter Ocean Governance] (describing scientists' resistance, until twenty years ago, to the idea that fishing could actually deplete stocks, even during a time when fishing fleets were being modernized and fishing efforts were expanding dramatically).

24 For a beautiful illustration of the neglect of a species that has little current commercial value, and very little charisma, see Eric Biber, The Application of the Endangered Species Act to the Protection of Freshwater Mussels: A Case Study, 32 ENvTL. L. 91, 113 (2002).

25 Scheiber, Ocean Governance, supra note 23, at 119-23. 
resources. ${ }^{26}$ Fisheries research is undoubtedly as advanced as it is because at least some fish species are wildlife commons-es with great commercial potential, and that status gives communities an incentive to study them in order to bring them into some form of control. But normally it is difficult to transform even a commercially valuable fishery, taken as a whole, into property; thus, incentives are much dispersed to learn about even this marketable environmental resource.

There are numerous other examples of information gaps and research lags-that is, higher levels and more rapid rates of investment in scientific/technological information that increase the value of things owned by some person or some specific group, vis-à-vis lower and slower rates of research into the consequences of these same activities on the larger environment. Take polychlorinated biphenyls (PCBs), for example: Sometime during or before the 1920s, investigators learned that PCBs were excellent insulating materials, and manufacturers subsequently put PCBs in everything from toasters to high-wire electrical transformers. ${ }^{27}$ It was only much later that researchers noticed that PCBs entered bodies of water, that they concentrated as they moved through the food chain from aquatic plants to the biggest fish, and that they might cause human medical problems as people ate the contaminated fish. ${ }^{28}$

Among environmental problems, those affecting human health are most likely to get attention. A person's body is in a certain sense a very intimate form of property, and issues about bodily health, like issues about more conventional property, concentrate the mind and give people a sharper incentive to learn. But even health problems can be slow to receive investigation and recognition, particularly when there is a lag between the body's receipt of the substance and the onset of disease. The slow learning curve about PCB contamination represents only one of many examples of this phenomenon. As automobiles became more widely used in the $1920 \mathrm{~s}$, for example, related industries found it useful and commercially valuable to learn how lead additives could improve the internal combustion engine. ${ }^{29}$ But even though some scientists soon became concerned about the potentially deleterious effects of airborne lead particles from auto exhaust, it took years before adequate funding emerged for research on the public

\footnotetext{
26 See Harry N. Scheiber, From Science to Law to Politics: An Historical View of the Ecosystem Idea and Its Effect on Resource Management, 24 EcologY L.Q. 631, 634-40 (1997) [hereinafter From Science to Law] (describing research on marine resources as early prototype for modern ecosystem approaches).

27 aARon Wildavsky, But Is It True? A Citizen's Guide to Environmental Health and SAFETY ISSUES 38-44 (1995). However, Wildavsky is skeptical about broader claims of toxicity in small residues of uningested PCBs. Id. at 42 .

28 For health effects, see the United States Environmental Protection Agency's Web page at http://www.epa.gov/opptintr/pcb/effects.html (last visited Nov. 23, 2002).

29 See Jamie Lincoln Kitman, The Secret History of Lead: A Special Report, ThE NATION, Mar. 20, 2000 (scathing accusation of industry promotion of lead additives, and suppression of information about potential harms), available at http://www.globalleadnet.org/pdf/TheSecretHistoryoflead.pdf. (last visited Nov. 24, 2002).
} 
health costs of these additives, and showed how they might contribute to neurological disorders. ${ }^{30}$

Had the damage from PCBs or lead particles remained with wildlife stocks or the wider air mantle instead of becoming a question of human health, many more years might have passed before anyone noticed the consequences of these substances; the information and research gap is likely to be much greater with such dispersed environmental resources. Consider chlorofluorocarbons (CFCs): Around 1930, technological research identified CFCs as stable substances and excellent refrigerants. Thereafter, CFCs came to be widely used in refrigerators and air conditioners, as well as in aerosol propellants. ${ }^{31}$ Decades passed, however, before scientists linked CFCs to the depletion of the upper atmospheric ozone layer. ${ }^{32}$ Similarly, manufacturers had enormous incentives to research and promote the beneficial effects of new chemical pesticides in the decades after the Second World War, since these substances did reduce insect damage and weeds. But neither farmers nor manufacturers had any particular incentives to find information that would link pesticides to the declining reproductive rates of bird populations, or to investigate how bird eggshells had grown too thin to support life. ${ }^{33}$ If anything, agricultural interests had more incentives to suppress this and other adverse environmental information. ${ }^{34}$

When one thinks about it, who does have any incentive to learn about such matters? If these non-market events have no immediate impact on either health or wealth, who cares? Environmentalists do, of course, but how do those incentives translate into actual scientific investigation?

30 Id.

31 John S. Hannah, Chlorofluorocarbons: A Scientific, Environmental and Regulatory Assessment, 31 A.F. L. REv. 85, 91-92 (1989). As Hannah notes, CFCs present health and climate change risks. Id. at $89-92$.

32 See F. Sherwood Rowland, Atmospheric Changes Caused by Human Activities, 27 ECOLOGY L.Q. 1261, 1264-70 (2001) (description by one scientist of the initial work in the 1970s on CFCs); see also John Warren Kindt \& Samuel Pyeatt Menefee, The Vexing Problem of Ozone Depletion in International Environmental Law and Policy, 24 TEX. INT'L. L.J. 261, 271 (1989) (describing hostile industry reaction to Rowland and co-author's work as "silenc[ing]" further scientific work for another decade).

33 See, e.g., WILDAVSKY, supra note 27, at 56-57, 65-70 (noting wider use of DDT after World War II and studies of potential harm in early 1960s; also noting research linking DDT to shell weakness in some bird species). Wildavsky, however, is generally skeptical of claims about the harms associated with DDTs. Id. at 58-63 (criticizing claims that DDT is harmful to humans). For more on historical DDT research, see Angus A. MacIntyre, Why Pesticides Received Extensive Use in America: A Political Economy of Agricultural Pest Management to 1970, 27 NAT. RESOURCES J. 533, 551 (1987) (noting both technical obstacles to better DDT testing and lack of industry economic incentive to improve testing in early years).

34 Numerous writers contend that industries sometimes actively undermine efforts to find information about adverse environmental effects of their products. See, e.g., John H. Cushman, Jr., After 'Silent Spring,' Industry Put Spin on All It Brewed, N.Y. TIMES, Mar. 26, 2001, at A14 (describing pesticide industry's efforts to counter bad publicity after publication of Rachel Carson's book); RoBert vaN DEN BOSCH, The Pesticide ConsPiRaCY 47-54, 59-72 (1978) (describing industry attacks on research into pesticide hazards); see also Kitman, supra note 29 (obstructive behavior toward gasoline lead additives research); KRIER \& URSIN, supra note 16, at 88-89 (automobile industry actions discounting smog research). 
Before turning to that question, let me stress again that I do not see private efforts and investment into research as evil. Private property motivates a great deal of research, and although it may be aimed at information with commercial potential, some of this information can have enormous side benefits for the environment. To take just one example, developments in computer science have made it much easier to model and track air pollution emissions. ${ }^{35}$

The larger point, however, is that rational economic decision-making favors investments in scientific investigation where there is some potential for private gains at the end of the road-that is, where the end-product can be turned into property. That same rational decision-making neglects scientific investigation where the benefits of knowledge may never become propertized but may instead be diffused and scattered through the public at large, or where payoffs from greater knowledge may be deferred for yearsanother form of diffusion. Information about such subjects could have enormous social benefits, but because the benefits are so dispersed, these subjects are likely to remain at most a matter of private concern to individual researchers, or simply a fortuitous by-product of better-funded research that has other commercial payoffs. And hence there is a gap between research whose results can be propertized relatively easily, and research whose results cannot be so easily propertized, even though the latter might much enhance our collective welfare. ${ }^{36}$

The aim, however, should not be to quell research, but to find ways to right the imbalance, so that knowledge of environmental consequences can catch up with knowledge of "propertizable" gains. Now, turning again to the question: What can help? One thing that can help, even quite substantially, is private law. A longstanding principle of nuisance law holds that owners of property may not use their property in ways that harm others. ${ }^{37}$ This means that if health damages from, say, PCBs, can be traced to the property owner, that owner may have to pay damages. In turn, potential liability gives people an incentive to learn about such damages. Tort lawyers, though much maligned, are ever on the lookout for products that might cause unexpected and unplanned harms, because those harms could pay off in contingency fees. On the opposite side of the coin, those who are potentially liable have an incentive to learn about the harms as well, and to try to alleviate them before being sued. Thus, tort law can help to redress the research imbalance with respect to environmental harms, a point much stressed by so-called "free market environmentalists." 38

35 See, e.g., Jonathan Remy Nash \& Richard L. Revesz, Markets and Geography: Designing Marketable Permit Schemes to Control Local and Regional Pollutants, 28 ECOLOGY L.Q. 569, 637-50 (2001) (describing computerized model for simulating air pollution levels and enabling pollutant trading).

36 See, e.g., MacIntyre, supra note 33 , at 558 (explaining that the inability to patent integrated pest management methods results contributed to long post-war lack of research into alternatives to chemical pesticides).

37 See RESTATEMENT (SECOND) OF TORTS $\$ \S 838-40$ (1979).

38 See, e.g., BRUCE YANDLE, COMMON SENSE AND COMMON LAW FOR THE ENVIRONMENT 114-15 (1997) (noting that anticipation of suit influences decisions about pollution and noting role of 
But tort law leaves information gaps in some environmental areas, even those that concern health, a matter that is generally on the public's mind. It is very difficult to prove a direct causal link between particular substances and health damages when those damages occur only incrementally over long time periods, or synergistically with other substances. Thus, a plaintiff in a toxic tort suit may face an insurmountable burden of proof against any given user or manufacturer of a damaging substance. ${ }^{39}$ This means that health harms from the substance may never get into the balance sheets of the user or manufacturer. If that is the case, then the manufacturers are unlikely to bother learning about these harmful side effects in any systematic way. Once again, this information shortage is generally much worse for environmental damage that is not directly linked to human health. Who will sue to protect the pigtoe mussel or the western prairie fringe orchid? Environmentalists, birders, and plant lovers might do so on their own, but then again, they might not even know of the danger or care sufficiently to try to do something about it. ${ }^{40}$ Absent such special commitment, no one will sue. The pigtoe and the orchid cannot sue for themselves, and no one else is likely to sue for them because no one owns them. ${ }^{41}$

It would seem that the obvious answer to such problems is to call for more formal governmental regulation to right the research imbalance. But we need to be cautious about regulation as a universal cure in such matters. Governmental agencies are certainly subject to special influences, and these influences often tend to run parallel to private interests. ${ }^{42}$ As James Krier and Clayton Gillette point out, the information gap is only one in a whole array of governmental failures within the environmental area-failures that tend to track the market failures of private activities. ${ }^{43}$ The authors cite voluminous "public choice" literature on this subject, which generally suggests that people with concentrated interests work harder to get a hearing from public officials than do people with diffuse interests, and that those with concentrated interests are more likely to influence public decision-making than are the widely dispersed and individually attenuated

contingency-fee attorneys in making such suits possible).

39 See Clayton P. Gillette \& James E. Krier, Risks, Courts and Agencies, 138 U. PA. L. REv. 1027, 1046-54 (1990) (noting plaintiffs' difficulties in litigating cases with widespread or latent risks, arguing that class action litigation does not necessarily help).

40 See Biber, supra note 24, at 159-60 (noting that environmentalists have seldom litigated threats to endangered freshwater mussels).

41 Many environmental statutes allow citizen suits, but some environmentalists are concerned about potential restrictions on standing. See John Echeverria \& Jon T. Zeidler, Barely Standing: The Erosion of Citizen "Standing" to Sue and Enforce Environmental Law (1999) (reporting judicial invalidations of citizen suits), available at $\mathrm{http} / / \mathrm{www}$.law.georgetown. edu/gelpi/papers/barely.htm; John Echeverria, Critiquing Laidlaw: Congressional Power to Confer Standing and the Irrelevance of Mootness Doctrine to Civil Penalties, 11 DUKE ENVTL. L. \& POL'Y F. 287 (2001) (describing subsequent developments in standing doctrine).

42 See, e.g., Kitman, supra note 29, at 24-26 (describing federal agencies' participation in "papering over" dangers posed by lead additives to gasoline in the 1920 s).

43 James E. Krier \& Clayton Gillette, The Un-easy Case for Technological Optimism, 84 MiCH. L. REv. 405, 420-24 (1985) [hereinafter Un-easy Case]; see James E. Krier, The Tragedy of the Commons, Part Two, 15 HARv. J.L. \& PUB. Pol'y 325, 338 (1992) (arguing that market failures creating environmental problems repeat themselves in the political arena). 
interests generated by environmental issues. ${ }^{44}$ Here too, health-related issues and medical research are likely to fare somewhat better than issues about such unowned substances as wildlife or the air mantle alone-the patient has a wallet and an insurance company, whereas the ozone layer has neither.

Thus, while people do turn to government to solve the environmental information gap, as they do to solve other information problems involving public issues (for example, weather forecasting or national defense intelligence), government does not come to this role simply by the force of nature. What government requires, at a minimum, is honesty and responsiveness to its citizenry. ${ }^{45}$ What government also requires is a citizenry that is alert, organized, and environmentally conscious-one that recognizes that environmental research must not only catch up but also generate expertise and a research agenda of its own. ${ }^{46}$ Environmentalists are by no means perfect as producers of information. They may focus disproportionately on dramatic events or charisma ${ }^{47}$ leading at least one commentator to conclude that they may be simply attempting to enhance their notoriety and hence fundraising opportunities. ${ }^{48}$ But drama, rhetoric, and aesthetics have an important and to date perhaps underexplored role in creating knowledge of non-market goods. ${ }^{49}$ In any event, by pursuing different directions for gathering information, organized environmental groups offset at least to some degree the normal paths that the market takes in generating research. ${ }^{50}$

44 Kreir \& Gillette, Un-easy Case, supra note 43, at 421-26; see also MacIntyre, șupra note 33 , at 571 (public choice analysis shows groups favoring pesticides have greater political influence than those opposed to pesticide use).

45 See Daniel C. Esty \& Michael E. Porter, National Environmental Performance Measurement and Determinants, in EnvTl. Performance Measurement: The Global Report 2001-2002, 24, 31, 41 (2002) (noting an important negative correlation between corruption and environmental performance, calling for rule of law as environmental matter).

46 See Sylvia Noble Tesh, UnCERTain Hazards: Environmental activists and Scientific PROOF 65-80 (2000) (describing environmentalists' influence on the agenda of some scientists).

47 See Biber, supra note 24, at 159-60 (observing that environmentalists may ignore noncharismatic species).

48 See Dale Oesterle, $A$ Clear-Headed Look at NGOs, 13 Colo. J. InT'L EnvTL. L. \& Pol'Y 129, 130-31 (2002) (analyzing nongovernmental organizations as competing for funds, suggesting that they spread alarmist news in order to attract grants and donations); see also Lakshman D. Guruswamy, Do GMOs Imperil Biosafety?, 9 IND. J. GLOBAL LEGAL STUD. 461, 478 (2002) (discussing Oesterle). For a more systematic account of environmental organizations as firms seeking revenues through membership, see Brian Kropp, Environmental Organizations: What Makes Them Tick?, in The MARKet MeEts THE Environment: Economic ANalysis of ENVIRONMENTAL POLICY 259, 264 (Bruce Yandle ed., 1999). Kropp's results are considerably more nuanced, however. See id. at 288-89 (identifying dramatic incidents as only one of a number of motivations in environmentalists' giving).

49 See Carol M. Rose, Environmental Lessons, 27 LoY. L.A. L. REv. 1023, 1041-47 (1994) (describing the role of aesthetics in environmental thinking).

50 See TESH, supra note 46, at 65-80 (noting new directions for research under environmental influence). Even Oesterle, though skeptical about nongovernmental organizations' motives, remarks that they play the role of the "loyal opposition" and raise consciousness about the "potentially corrosive effect" of profit motives on corporate activity. Oesterle, supra note 48 , at 134 . 
Given a certain level of pressure from environmentally engaged and organized citizens, governments can indeed play an important role in overcoming the environmental information gap. First, governments invest directly in important scientific investigation relating to environmental issues. For years, governments the world over have collected information about marine environments, though often with an eye to preserving the viability of national fishing industries. ${ }^{51}$ We owe some of our knowledge of rainforest depletion and global warming to government-sponsored satellite technology. ${ }^{52}$ Cold War-era naval intelligence technology, once used to detect enemy ship and submarine movements, now assists in the study of whales and other marine mammals. ${ }^{53}$ Governments give grants to universities for all kinds of investigations into public health and natural resource management.

To be sure, many public research investments are directed in the first instance at something other than environmental factors, such as collecting military intelligence or bolstering mining, fishing, or agricultural industries. Indeed, to some degree such research programs can increase the environmental information gap, just as private research investment does. Agriculture school grants, for example, are likely to study concentrated animal feeding technology before-and more vigorously than-they focus on the wastes and odors emanating from feedlots. ${ }^{54}$ Given the "public choice" factors at work in public funding, this should be no surprise.

Interestingly enough, governmental regulatory activity, rather than direct research grants, may generate more information that rights the balance about environmental matters. Even though a number of these regulatory programs are criticized for their clumsiness and expense, they do force private actors to take cognizance of the environmental consequences of their plans, because these regulatory programs put environmental concerns into firms' balance sheets. One type of legislation, sometimes dubbed "gatekeeper" regulation, applies particularly to new pesticides and

51 See From Science To. Law, supra note 26, at 637 n.15 (describing national and international governmental and intergovernmental fisheries research, particularly that of one international organization that began in 1902).

52 See, e.g., Douglas A. Kysar, Sustainability, Distribution, and the Macroeconomic Analysis of Law, 43 B.C. L. REV. 1, 2 (2001) (noting the use of satellite technology to confirm global warming predictions); Nicholas A. Robinson, Forest Fires as a Common International Concern: Precedents for the Progressive Development of International Environmental Law, 18 PACE ENVTL. L. REv. 459, 475 (2001) (noting the use of satellites to monitor vast forest fires in Indonesia); Allison F. Gardner, Environmental Monitoring's Undiscovered Country: Developing a Satellite Remote Monitoring System to Implement the Kyoto Protocols Global EmissionsTrading Program, 9 N.Y.U. ENVTL. L.J. 152, 153 (2000) (describing the current use of satellites in climate monitoring).

53 William J. Broad, Scientists Gain Access to the Navy's "Deep Ears" on the Ocean, N.Y. TTMES, July 28,1998 , at F4.

54 See Don F. Hadwiger, The Politics of Agricultural Research 198 (1982) (concluding his study of agricultural research by saying that this research has been dominated by the agricultural industry, and by its goals of enhancing production and reducing labor, while neglecting or even suppressing research into environmental, consumer safety, and social consequences). 
chemicals. ${ }^{55}$ Because at least some of these substances are created for their toxicity, and others are related to known toxins, we suspect they may cause adverse consequences to the public health or the environment. Hence, we require that producers pre-screen their products for safety before the products enter the market. For instance, the Federal Insecticide, Fungicide, and Rodenticide Act (FIFRA) ${ }^{56}$ as well the Toxic Substances Control Act (TSCA $)^{57}$ both require the producers of new products in these areas to prove their products' safety in advance of entering the market. ${ }^{58}$ This of course means that both regulators and regulated industries must learn a good deal about the products, including their effects on animals and plants.

A second (and much maligned) type of information-forcing regulation is "impact analysis" under a statute like the National Environmental Policy Act (NEPA) ${ }^{59}$ Under this type of legislation, major governmental participation in a project triggers the requirement that project coordinators assess the project's environmental impact, and they may also have to explore alternatives and possible mitigation measures. Such legislation essentially represents a direct order to, say, a highway department to investigate the environmental consequences of its projects, even though the highway department has no particular interest in those consequences. This kind of legislation affects private parties' environmental information-gathering as well, because private firms often contract to build the highways in question. To do so, they must know not just about asphalt and cement, but also whether the asphalt and cement will disrupt indigenous plant life, local streambeds, or other environmental factors.

A third type of legislation has been called "technology-forcing." This type of legislation originated with the major air pollution control statutes that were enacted in the 1970s, such as the Clean Air Act (CAA); the early targets of such statutes were major industrial plants and automobile manufacturers. ${ }^{60}$ This legislation was designed to set environmental standards so stringently that industries could not meet them with current technology, thus forcing industries to invest in research into new pollution control technology, or better yet, into less polluting engines. ${ }^{61}$ As with impact analysis under NEPA, the technology-forcing aspects of the CAA indirectly required auto manufacturers to put research funds into generating environmental information even though they had no other business-related reason for doing so, and many business-related reasons not to bother: Not

55 Peter Huber, Exorcists vs. Gatekeepers in Risk Regulation, REgulation, Nov./Dec. 1983, at 23. Huber opposes such gatekeeping forms of regulation as unduly burdensome on newer technologies, which he thinks are likely to be safer. Id. at 28-29.

567 U.S.C. $\$ \S 136-136 y(2000)$.

5715 U.S.C. $\$ \S 2601-2692(2000)$.

58 Id. $\S 2603(\mathrm{a}) ; 7$ U.S.C. $\S 136 \mathrm{a}$.

5942 U.S.C. $\$ \$ 4321-4370 \mathrm{e}(2000)$.

60 James A. Henderson, Jr. \& Richard N. Pearson, Implementing Federal Environmental Policies: The Limits of Aspirational Commands, 78 CoLUM. L. REv. 1429, 1445-46 (1978).

61 See, e.g., Natural Res. Def. Council, Inc. v. United States Envtl. Prot. Agency. 655 F.2d 318 (D.C. Cir. 1981) (upholding technology-forcing standards for "trap-oxidizer" pollution control device though durable model currently unavailable). 
only is such research expensive, but if only one industry participant conducts the research, that participant can lose competitive market share. Critics argue, however, that technology-forcing may prove counterproductive because it sets unrealistic goals or because, like other command-and-control legislation, it is costly and overly dirigiste ${ }^{62}$

A fourth type of legislation effectively beefs up older tort law. As I mentioned earlier, traditional tort law has some limitations when it comes to environmental matters. Among other things, no plaintiffs may have an interest sufficient to establish standing where the resources are not owned by anyone in particular. Nevertheless, modern legislation extends older tort regimes to include liability for non-market goods. For example, in the case of an oil spill, a ship now may be liable for "damage to natural resources," as may a polluting chemical factory for other toxins it releases. ${ }^{63}$ This type of legislation may encourage investment in technologies to stop vessel leaks or avoid uncontained chemical waste. Here too, however, critics have complaints: determining damages for non-market natural resource harms has proved particularly controversial. ${ }^{64}$

One other much-discussed and more recent regulatory technique I will call a regime of "hybrid property rights." A "hybrid property" regime converts environmental factors into property-like allowances that must be purchased by users. This technique too can have an impact on the generation of environmental information. The best-known example involves tradeable environmental allowances in sulfur dioxide $\left(\mathrm{SO}_{2}\right)$. This gas is a precursor to acid rain, and much of it is produced by burning coal, a major fuel for power plants in the United States. The Clean Air Act Amendments of 1990 limited the total amount of $\mathrm{SO}_{2}$ that power plants could produce annually to what was believed an environmentally safe level. The Act further provided that this overall amount be divided into one-ton annual allowances, and required that coal-burning plants have an allowance for each ton of $\mathrm{SO}_{2}$ that they produce-allowances that after initial allocations must be acquired by purchase or trade. ${ }^{65}$ The hope implicit in these measures is that when pollution generators have to buy these hybrid, governmentally created allowances, they will have an incentive to search for better pollution control methods so that they can avoid the expense or sell their excess allowances to others.

62 For an example of an early critique, see Henderson \& Pearson, supra note 60, at 1448-53 (criticizing technology forcing as "aspirational commands" that undermine real efforts).

63 Oil Pollution Act of 1990, 33 U.S.C. $\$ 2702(b)(2)(A)(2000)$ (vessel liable for damages to natural resources in case of oil spill); Comprehensive Environmental Response, Compensation, and Liability Act of $1980,42 \cdot$ U.S.C. $\S 9607(\mathrm{a})(4)(\mathrm{C})(2000)$ (liability of damage to natural resources).

- 64 An important method for evaluating natural resource damage is "contingent valuation," an effort to establish non-market prices by direct inquiries into willingness-to-pay. Contingent valuation is widely criticized and widely praised. For some of the different viewpoints, see Symposium on Contingent Valuation, 8 J. ECON. PERSP. 3-63 (Fall 1994).

65 Air Pollution Control Act, 42 U.S.C. $\S \S 7401-7671 q$ (2000), Subchapter IV-A, Acid Deposition Control, $\$ \S 7651-76510$. 
In effect, a hybrid property rights scheme should do for environmental research what conventional property rights do for product research: Hybrid property rights give actors economic incentives to learn, because the results of learning can avoid expense and create profit. Firms that must purchase emission allowances (or that can sell excess allowances) have good reason to learn what their emissions are and how they might be minimized; firms that can invent new pollution control devices now have a market for their products and hence an incentive to do further research ${ }^{66}$ Moreover, air pollution control is not the only arena for these hybrid environmental property rights. New types of hybrid rights are showing up in fisheries management, particularly in Australia and New Zealand, where they are known as "individual fishing quota" (IFQ) or "individual tradeable quota" (ITQ) ${ }^{67}$ In a particularly encouraging development, holders of these fishing rights have been learning to cooperate to enhance the fisheries' supporting ecosystems. ${ }^{68}$ Similarly, hybrid environmental rights have been much discussed in connection with the reduction of the carbon dioxide emissions that produce atmospheric global warming. ${ }^{69}$

Fundamentally, all these schemes of hybrid rights are variants on the idea of property: Property induces careful management, including the imaginative investigation of alternatives. By extending property ideas into the previously unowned realms of environmental resources, hybrid rights also extend property's inducements to learn into these areas, and they thus help right the imbalance of learning as between private goods and public environmental ones.

Hybrid property schemes in the environment certainly have had their critics, many focusing on problems of monitoring and the technical difficulties or incommensurabilities involved in trading some environmental goods for others. ${ }^{70}$ For example, pollutant trading could overload certain geographical areas with air or water problems-something that is particularly objectionable if those areas are already poor. Similarly, wetlands trades might occasion very different patterns of flood control,

66 Proponents of hybrid property rights approaches have long stressed their encouragement of innovation by comparison to command-and-control regulation. See, e.g., Richard B. Stewart, Controlling Environmental Risks Through Economic Incentives, 13 CoLUM. J. ENVTL. L. 153, 160 (1988) (describing innovation as one of several advantages of such measures as pollution charges and transferable allowances).

67 See Carol M. Rose, Expanding the Choices for the Global Commons: Comparing Newfangled Tradable Allowance Schemes to Old-Fashioned Common Property Schemes, 10 DUKE ENVTL. L. \& POL'Y F. 45, 51 (1999) and sources cited therein for a description of some aspects of hybrid rights in fishing. [hereinafter Expanding the Choices].

68 Id. at 70.

69 Id. at 51.

70 See, e.g., James Salzman \& J. B. Ruhl, Currencies and the Commodification of Environmental Law, 53 STAN. L. REv. 607 (2000) (stressing monitoring and measurement issues, and non-fungibility of environmental services that might be traded); Expanding the Choices, supra note 67, at 60-62 (same); see also Alison Rieser, Prescriptions for the Commons: Environmental Scholarship and the Fishing Quotas Debate, 23 HARv. ENVTL. L. REv. 393, 417 (1999) (arguing that the greatest problem for fishing hybrid rights is the lack of attention to ecosystem interaction). 
animal habitat, and water purification in the different locations involved in trades. These are serious issues, and they need to be addressed in hybrid rights programs.

But interestingly enough, some of the most serious criticisms of hybrid environmental rights have been ethical ones. The communitarian political thinker Michael Sandel voiced these doubts most sharply in a brief opinion article, arguing that tradeable environmental allowances allow people to buy a right to do wrong. ${ }^{71}$ Indeed, he argues that the whole rhetoric of property in the environment is a kind of commodification that undermines our moral objections to pollution-our common sense that we should be doing all we can to avoid environmental degradation.

Some empirical research suggests, however, that the opposite is true, and that citizens are less likely to cheat on environmental or public goods when these are priced rather than forbidden. Apparently, user payments make the scheme seem more fair to non-users and more worthy of respect. ${ }^{72}$ But even if these tentative research data prove to be limited or mistaken, it may well be that the ethical problem embedded in the rhetoric of propertypaying to do wrong-is simply dwarfed by the much larger ethical problem of an imbalance between private knowledge-generation and environmental knowledge-generation. Property rights in some ways represent a concession to human frailties, and it is no wonder that property has been eschewed by utopian thinkers throughout history. ${ }^{73}$ But if we frail human beings can use the institution of property to help solve the knowledge gap, and thus encourage the investigation into ways to avoid environmental degradation as our other technical knowledge advances, we owe it to ourselves to try.

Finally, there are undoubtedly many dedicated scientists who bridle at the idea that scientific learning is simply the economic commodity of information, where productive incentives respond to a market for ideas. And they are right. It is unquestionably false to suppose that the scientific endeavor is simply a producer of commodities and nothing more. But surely scientific research is a market-driven activity in some measure-indeed in a very considerable measure-especially when one takes into account the market's secondary influence on politics. That means we need to focus on ways to assure that scientific investigation systematically accounts for the big picture that includes environmental well-being, along with other elements of our public welfare, and not just the little picture that narrows toward tangible and commercially recognizable financial gains. ${ }^{74}$

71 Michael J. Sandel, Op-Ed, It's Immoral to Buy the Right to Pollute, N.Y. TIMES, Dec. 15, 1997, at A23.

72 See Lior Jacob Strahilevitz, How Changes in Property Regimes Influence Social Norms: Commodifying California's Carpool Lanes, 75 IND. L. J. 1231, 1291-92 (2000) (summarizing study of San Diego highway program requiring payment for non-carpooler usage of fast lane; the study reports an increase in carpooling and a decrease in cheating, and analogizes to pricing of environmental emissions).

73 Carol M. Rose, Evolution of Property Rights, in 2 New Palgrave Dictionary of Economics AND THE LAW 93 (Peter Newman ed., 1998).

74 Id. at 97. 
[Vol. 32:755

Since the seventeenth century, science has changed the world. I am not at all convinced that scientific and technological progress has been an unalloyed good for the environment. But neither am I at all convinced that the problem is modern science's machismo-its drive to dominate a weak and yielding nature. If anything, the genuinely problematic aspect of science for environmental ethics is the opposite: That the scientific drive evaporates in the face of nature in its most vast sense. All too often, rational investment decisions in scientific research exhibit only profound disinterest in the huge, diffuse, global commons of nature. With respect to science, it is that disinterest that environmental ethics must most urgently address. 